\title{
Process effluents and mine tailings: sources, effects and management and role of nanotechnology
}

\author{
Dipti Prakash Mohapatra ${ }^{1} \cdot$ Deepak M. Kirpalani $^{1}$
}

Received: 31 May 2016/Accepted: 3 October 2016/Published online: 19 December 2016

(C) Springer International Publishing Switzerland 2016

\begin{abstract}
Increasing population levels, growing economies, rapid urbanization and changes in consumption patterns have increased the demand for raw materials such as base and precious metals, leading to growing concerns regarding their availability and the global efficiency of the mine supply chain. Mine tailings, consisting of process effluents that are generated in a mineral processing plant, are generally transferred to tailings ponds/impoundments to meet environmental regulations and site-specific factors before discharge. Most mining activities induce an impact on their geochemical environment (e.g., water, groundwater) due to the presence of metal-rich tailing deposits. The need for a comprehensive framework for mine tailings management that promotes sustainable development is therefore becoming increasingly recognized by the mining industry. Therefore, for sustainable rehabilitation and disposal of mining waste, the sources and mechanisms of pollutant generation and their subsequent effect on environment and sustainable treatment methods are critical. This review includes information on different sources of mining waters and its effect on groundwater contamination and ecological effects. The review also encompasses a broad range of mine water treatment strategies available for innovative management of mining tailings with a specific emphasis on the role of nanoparticles in the management of mine waters.
\end{abstract}

Deepak M. Kirpalani

Deepak.Kirpalani@nrc-cnrc.gc.ca

1 Energy, Mining and Environment Portfolio, National Research Council of Canada, 1200 Montreal Road, Ottawa, ON K1A 0R6, Canada
Keywords Mining wastes - Water contamination · Ecological effects · Sustainable management . Nanoparticles

\section{Introduction}

Water use and energy consumption in mining have been identified as two key business risks by the mining industry. Further, it is identified that future availability of water supply is a significant risk for the hard rock mining sector and a range of treatment methods for mitigating the impending risk are essential as competition for access to water increases with increased demand [98]. The risks are due to expected water shortages, increased regulatory limitations on water use, as well as other environmental aspects including environmental regulatory compliance and social licenses to operate (SLO). In recent times, many governments have embraced the concept of integrated water resources management (IWRM) in an effort to balance water allocation across competing social, environment and economic demands [1]. Further, mining, minerals and energy supply networks play an important role in IWRM implementation. Mine and other process operations effluent and tailings management systems can impose long-term and sometimes permanent impacts on water resources [7], thereby impeding water accessibility for future generations. This is especially controversial when resource deposits are located in water scarce, environmentally or culturally sensitive regions. Water access by mining companies can also be controversial when the communities surrounding operations do not themselves have adequate access to freshwater for the sustainability of communities [45].

Water management focuses on reducing mine water use and improving management by understanding independent 
aspects of mine water interactions, water and wastewater treatment strategies and efficient water use process schemes. Among those, the predominantly studied aspects are impacts of mining voids on water resources and surrounding water bodies, e.g., groundwater table drawdown and groundwater contamination due to mining activities [89]. Acid mine drainage, the leaching of mine drainage water, from waste rock piles, and release of untreated water from impoundments into groundwater aquifers are potential sources of water contamination from mines. Groundwater contamination is of particular concern where the groundwater feeds surface streams or lakes, or where the groundwater is directly a source of potable water for the community. Because of these concerns, groundwater contamination prevention is a component of modern mine design, and a network of groundwater monitoring wells is installed in order to assess the sufficiency of preventive measures and provide an early warning system for spills or leaks [54]. Once contamination is detected, a decision needs to be made on whether to initiate corrective measures and the type of action varies according to the type of contamination and its hydrogeologic and geographic settings. There are regulatory agencies in the international, federal, provincial and local level that have requirements to prevent or treat different types and concentrations of groundwater contamination. Further, in consideration of the future groundwater quality, the question is whether or not to take action that would partially or completely prevent continued or increased contamination.

Water endowments can also be affected by acid mine drainage (AMD), which can occur when minerals associated with ore bodies decompose in the surficial environment. Mining activities trigger this phenomenon by exposing walls of open pits, underground structures, and crushed waste rock and tailings to water and oxygen, which can generate AMD containing a number of potentially harmful constituents. AMD is among the most serious and potentially enduring legacies of the mining industry throughout the world [3]. The detrimental outcomes associated with AMD can impact three environmental areas such as (1) contaminated drinking water; (2) disrupted growth and reproduction of aquatic plants and animals; and (3) corroding effects of acid on infrastructure such as bridges, railways and ships. It was also reported that a region impacted by $\mathrm{AMD}$ often has a decline in valued recreational fish species such as trout as well as a general decline in outdoor recreation and tourism. AMD can have severe impacts on aquatic resources including (1) stunted terrestrial plant growth and can affect wetlands; (2) contaminated groundwater resulting in increased water treatment costs; and (3) damaged concrete and metal structures [27].
Mine waters typically pose an additional risk to the environment as they often contain elevated concentrations of metals (iron, aluminum and manganese, and other heavy metals) and metalloids (mainly arsenic poses greatest concern [6]. Existing and upcoming treatment technologies to clean contaminated mine water can be categorized as active or passive treatment. Active treatment technologies require the input of energy and chemicals, and passive treatment uses only natural processes such as gravity, microorganisms and/or plants in a system. The treatment technology used for mine water treatment depends on different factors to be considered such as (1) the pollution level, (2) chemicals/biological materials required for treatment, (3) the water body size and (4) the required discharge water quality standards. In order to protect the ecosystem and end users or create public awareness on mining water effects, it is required to treat the mining water before further contamination to groundwater or surface water. Hence, the purpose of this review is to provide information on different sources of mining water and its effect on groundwater contamination and ecological effects. The review also includes different treatment options available for innovative management of mining tailings and the role of nanoparticles.

\section{Source of mining water}

It is important to understand the sources of water that mines use in their operations as well as the effluent discharged to the environment. Water is used in mining operations for processing of minerals, recovery of metals, dilution and to meet the domestic water requirements on site among others. A range of physical processes during mining operation that require water include grinding, flotation, gravity concentration, dense medium separation and hydrometallurgical processes. Further, to leach the gold-containing soil, large quantity of water is used in an open-pit gold mining system [16]. Due to the lower concentration in ores, gold, platinum, diamonds, nickel and copper are associated with the highest water consumption. Furthermore, more water is needed per each unit of production as ore grades are declining globally [58].

To separate the minerals in a heap-leaching base, specific chemicals, including cyanide and sulfate, are used with water to wash the soil. In mining industry (mainly for extraction of minerals), water is used for different operational activities such as (1) transport of ore and waste in slurries and suspension; (2) physical separation of material such as in centrifugal separation; (3) separation of minerals through chemical processes; (4) cooling systems around power generation; (5) dust suppression, both during 
Fig. 1 Possible mining operation impacts on water contamination

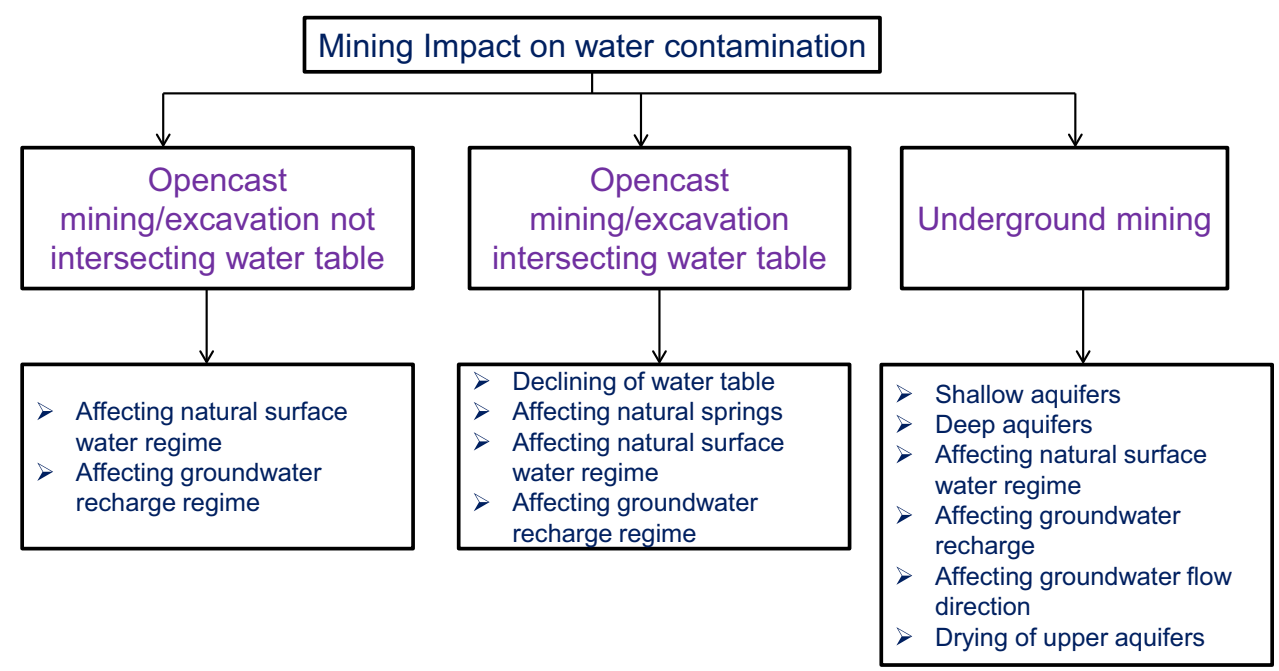

activities and the security of their access to it. Further, to increase the public acceptance of mining, the mine tailings including the process-affected water must be treated for reuse or safe discharge to the environment [79].

\section{Groundwater and surface water contamination by mining}

Mining affects groundwater and river water through heavy use of water in processing ore and through discharged mine effluents and seepage from tailings and waste rock impoundments. The high metal concentrations and acidity observed in waters from mining areas depend on several parameters and processes, such as the buffering capabilities of the host rock, ore deposits depth and permeability, and the type and abundance of the metal-bearing sulfides. Mining operation impacts on water contamination are shown in Fig. 1.

Among the mining activities, sulfide mineralization is notorious for producing waters with high metal contents and effect the water quality of groundwater and river water. Process-affected water of sulfide mineralization contains arsenic which considered being toxic in the environment even at low levels. Arsenic contamination by mining activities is space confined, and arsenic content near to the mining sites reaches levels higher than the natural background concentrations [85]. Elevated concentrations of arsenic in groundwater are reported from several countries of the world such as India, China, Nepal, Vietnam, Argentina, Chile, Cambodia, Mexico and USA [14, 85]. Different concentrations of arsenic, uranium, selenium and sulfate observed in groundwater and surface water are presented in Table 1. Water resources affected by radioactive and chemical contamination in the former uranium mining and milling sites of Mailuu-Suu 
Table 1 Country-wise concentration of arsenic, uranium, selenium and sulfate in groundwater and surface water

\begin{tabular}{|c|c|c|c|c|}
\hline Country & Contaminant & Sample & Concentration & References \\
\hline \multirow[t]{3}{*}{ India } & \multirow[t]{6}{*}{ Arsenic } & Groundwater & $22.1 \mu \mathrm{g} / \mathrm{L}$ & Das et al. [26] \\
\hline & & Groundwater & $1466 \mu \mathrm{g} / \mathrm{L}$ & Chakraborti et al. [19] \\
\hline & & Groundwater & $>0.01 \mathrm{mg} / \mathrm{L}$ & Verma et al. [90] \\
\hline \multirow[t]{3}{*}{ Bangladesh } & & Groundwater & $>50 \mu \mathrm{g} / \mathrm{L}$ & Bhattacharya et al. [14] \\
\hline & & Groundwater & $118 \pm 91 \mu \mathrm{g} / \mathrm{L}$ & Jung et al. [41] \\
\hline & & Groundwater & $115-349 \mu \mathrm{g} / \mathrm{L}$ & Rahman et al. [75] \\
\hline Kyrgyzstan & & & Up to $10 \mu \mathrm{g} / \mathrm{L}$ & Alvarado et al. [4] \\
\hline \multirow[t]{3}{*}{ Bolivia } & & Surface water & - & Salvarredy-Aranguren et al. [80] \\
\hline & & Surface water & $8.6-117 \mu \mathrm{g} / \mathrm{L}$ & Munoz et al. [66] \\
\hline & & Groundwater & 3-3497 $\mu \mathrm{g} / \mathrm{L}$ & \\
\hline Netherlands & & Groundwater & $10-26 \mu \mathrm{g} / \mathrm{L}$ & Gude et al. [37] \\
\hline Italy & & Groundwater & $230 \mu \mathrm{g} / \mathrm{L}$ & Reyes et al. [76] \\
\hline Mexico & & Groundwater & $0.45 \mathrm{mg} / \mathrm{L}$ & Wurl et al. [96] \\
\hline \multirow[t]{2}{*}{ India } & \multirow[t]{14}{*}{ Uranium } & Groundwater & $71.6 \mu \mathrm{g} / \mathrm{L}$ & Milja et al. [60] \\
\hline & & Groundwater & $0.3-48 \mu \mathrm{g} / \mathrm{L}$ & Singh et al. [83] \\
\hline China & & Surface water & $3.85-7.57 \mu \mathrm{g} / \mathrm{L}$ & Juanjuan et al. [42] \\
\hline Mexico & & Groundwater & $1.0-7.2 \mu \mathrm{g} / \mathrm{L}$ & Montufar et al. [64] \\
\hline USA & & Groundwater & $50 \mathrm{mg} / \mathrm{L}$ & Abdelouas et al. [2] \\
\hline Korea & & Groundwater & $3610 \mu \mathrm{g} / \mathrm{L}$ & Shin et al. [81] \\
\hline Australia & & Groundwater & $0.001-2.77 \mu \mathrm{g} / \mathrm{L}$ & Atkins et al. [8] \\
\hline Germany & & Surface water & $0.33 \mu \mathrm{g} / \mathrm{L}$ & Liesch et al. [53] \\
\hline Brazil & & Groundwater & $0.01-1.4 \mu \mathrm{g} / \mathrm{L}$ & Silva and Bonotto [84] \\
\hline Cyprus & & Groundwater & $0.1-40 \mu \mathrm{g} / \mathrm{L}$ & Charalambous et al. [20] \\
\hline Mongolia & & Groundwater & $0.01-57 \mu \mathrm{g} / \mathrm{L}$ & Nriagu et al. [67] \\
\hline Myanmar & & Groundwater & $11 \mu \mathrm{g} / \mathrm{L}$ & Bacquart et al. [9] \\
\hline Spain & & Groundwater & $1.93 \mu \mathrm{g} / \mathrm{L}$ & Forcada and Alegre [33] \\
\hline Kyrgyzstan & & Groundwater & $10 \mu \mathrm{g} / \mathrm{L}$ & Alvarado et al. [4] \\
\hline India & \multirow[t]{4}{*}{ Selenium } & Groundwater & $0.01-35.6 \mu \mathrm{g} / \mathrm{L}$ & Dhillon and Dhillon [30] \\
\hline USA & & Groundwater & $<0.5-4070 \mu \mathrm{g} / \mathrm{L}$ & Mills et al. [61] \\
\hline Chile & & Groundwater & Up to $800 \mu \mathrm{g} / \mathrm{L}$ & Leybourne and Cameron [51] \\
\hline Norway & & Surface water & $22-59 \mathrm{ng} / \mathrm{L}$ & Okelsrud et al. [68] \\
\hline \multirow[t]{2}{*}{ USA } & \multirow[t]{2}{*}{ Sulfate } & Groundwater & $427 \mathrm{mg} / \mathrm{L}$ & Miao et al. [59] \\
\hline & & Groundwater & $40 \mathrm{nmol} / \mathrm{L}$ & Toran $[88]$ \\
\hline Brazil & & Groundwater & $0.03-3.91 \mathrm{mmol} / \mathrm{L}$ & Bertrand et al. [10] \\
\hline
\end{tabular}

(Kyrgyzstan) were studied by Alvarado et al. [4]. They observed that the groundwater near to the mining site has an elevated level of uranium (up to $10 \mu \mathrm{g} / \mathrm{L}$ ), and in some sites, the WHO guideline value of $10 \mu \mathrm{g} / \mathrm{L}$ for arsenic in water was exceeded [4]. Salvarredy-Aranguren et al. [80] investigate the contamination of surface waters in the Milluni Valley (Cordillera Real, Bolivia) by mining wastes to identify contamination sources and sinks, and contamination control parameters. They reported that potentially harmful elements with significant high concentrations exceeded the WHO water guidelines for human consumption in discharge waters. They also reported that the oxidation of sulfide minerals in mining waste (highly acidic condition) favored the enrichment of dissolved metals in surface waters downstream from the mine. Contamination of groundwater in a part of Tarkwa mining area, Western Ghana, was studied by Bhattacharya et al. [13]. They reported that the main contaminants are manganese and iron, and in some groundwater samples, the concentration of arsenic and aluminum exceeded the WHO regulations due to the acid mine drainage. They also concluded that adsorption processes play an important role to control the metal concentrations in groundwater contaminated by mining activities. In $\mathrm{Au}-\mathrm{As}$ mining activities, contamination of stream waters and groundwater by arsenic is a major issue. Adsorption and desorption are two of the major processes controlling arsenic mobility in soils, sediments and ultimately in groundwater and surface water. Arsenic 
preferentially adsorbs on iron oxides, carbonates, clays and organic materials [85].

Sracek et al. [86] investigate the mining-related contamination of the Kafue River network in the Copper belt, northern Zambia. They concluded that due to the rapid precipitation of iron oxides and hydroxides as well as adsorption and/or co-precipitation of copper, and cobalt, the impact of mining activities on the Kafue River is relatively limited. Kayzar et al. [43] measured the uranium concentration in Red Rock Creek in the Stanislaus National Forest of California to investigate the leaching of uranium to the natural surface stream from a point source of Juniper Uranium Mine. They reported that as a result of minederived contamination, water $\left({ }^{234} \mathrm{U}\right) /\left({ }^{238} \mathrm{U}\right)$ ratios are $67 \%$ lower than in water upstream of the mine (1.11-1.12 \pm 0.009$)$ in the contaminated waters.

Among the different sources for sulfate emission into groundwater, coal mines and metal mines are considered as the main source due to the presence of large quantities of sulfide minerals [59]. Dhakate et al. [29] studied the impact assessment of chromite mining on groundwater through simulation modeling in Sukinda chromite mining area, Odisha, India. They reported that the concentration of $\mathrm{Cr}$ (VI) exceeds the permissible limits in some samples of groundwater, surface water and mine water and mine seepage. The $\mathrm{Cr}(\mathrm{VI})$ content was high near the ore bodies, and it decreased with distance away from ore body. In groundwater samples, the $\mathrm{Cr}(\mathrm{VI})$ concentration varied from 0.009 to $0.043 \mathrm{mg} / \mathrm{L}$ for post-monsoon period and $0.032-0.452 \mathrm{mg} / \mathrm{L}$ for pre-monsoon period. The variation in concentration of $\mathrm{Cr}(\mathrm{VI})$ was due to the migration of pollutant from waste rock dump during the rainy season.

Metal mining especially $\mathrm{Pb}-\mathrm{Zn}$ mine severely contaminates groundwater quality. Concas et al. [24] studied the mobility of heavy metals from tailings to groundwater in a mining activity contaminated site and reported the contamination of groundwater became worse and strongly visible due to the red coloring of bed stream sediments as a consequence of abundant Fe(III)-hydroxides precipitation. The presence of elevated concentrations of heavy metals in groundwater and surface water near to mining sites raises the way to study different ecological effects of these contaminants.

\section{Ecological effects}

Most mining activities induce an impact on their environment (e.g., water, groundwater) due to the presence of metal element (ME)-rich tailing deposits [71]. The effects of contamination from abandoned mine waste occur at all levels of biological organization, and there are potential indicators at each level $[22,23]$. Several indices are used to characterize environmental and ecological risks such as (1) sediment quality guidelines (SQGs) [87]; (2) risk assessment code (RAC) [56]; (3) risk index (RI) [74]; and (4) the WHO standards. AMD releases significant amounts of As and metalloids to the environment through runoff and stream waters, soils, sediments and groundwater and further introduced into the food chain [92]. Further, different studies reported the adverse effect of mining activities on environment such as water and soil contamination and biodiversity loss [55]. The extension of agricultural fields and suburban development has encroached many mining affected sites worldwide creating a health risk to residents living there [100].

Pascaud et al. [72] studied the risk assessment of $\mathrm{Cd}, \mathrm{Pb}$ and $\mathrm{Zn}$ in Ghezini Wadi, northern Tunisia, contaminated by mining wastes in a carbonated semiarid context. The results showed that according to the ecological risk assessment, $\mathrm{Cd}$ is the element that presents a very high potential ecological risk from upstream to downstream and contributes the most to the RI index. They also reported that close to the tailings site, $\mathrm{Pb}$ poses a high ecological risk and toward the downstream sediment the risk declines considerably. Furthermore, risk assessment of copper in mining site was carried out by Bunton et al. [17]. They reported that in white perch (Morone americana), hepatic copper storage (Wilson's) disease is characterized by the progressive accumulation of copper in hepatic lysosomes bound to metallothioneins.

Besser et al. [12] studied the toxicity of sediments downstream of lead-zinc mining areas in southeast Missouri, using pore-water toxicity tests with the daphnid, Ceriodaphnia dubia, and chronic sediment toxicity tests with the amphipod, Hyalella azteca. The results demonstrated that toxic effects were significantly correlated with metal concentrations such as lead, nickel, zinc and cadmium in sediments and this is contributed to adverse ecological effects in streams. Allert et al. [5] studied the ecological effects of lead mining on Ozark streams and also conducted toxicity analysis of mining-derived metals to the woodland crayfish (Orconectes hylas) through a chronic 28-d exposure. They reported that the crayfish survival and biomass compare to reference and downstream sites were significantly lower at mining sites. Further, they reported that the higher concentration of metals at mining sites was negatively correlated with caged crayfish survival. The eco-toxicity of chromium mine waste using earthworm and microbial assays was carried out by Coller-Myburgh et al. [25]. They carried out a series of experiments to determine the effect of chromium mine waste on soil microbial community and soil invertebrate's activity. They reported that the chromium mining did have an eco-toxic effect on enzymatic activity, as the material which exceeded the $\mathrm{Cr}$ benchmark for microorganisms showed the least amount of 
enzymatic activity. Moriarty et al. [62] studied the arsenic toxicity in lake sediments affected by mining activities in the Quinsam River watershed, British Columbia. They carried out the bioaccessibility tests by considering the solubility and availability of arsenic to benthic organisms and reported that in sediment the bioaccessibility of arsenic is moderate $(8-35 \%)$. Further, they concluded that for arsenic sediment toxicity testing, amphipod, Corophium volutator, can be used as a promising candidate.

Although modern mining practices incorporate efficient extraction technologies and operate within environmental regulations, still many studies showed the expose of aquatic biota to mining wastes and its toxic effects. Oughton et al. [69] studied the ecological risk assessment of uranium and radium in Central Asian mining sites by using ERICA assessment tool. The ERICA assessment tool, a product of the 6th Framework project ERICA, is one of the most comprehensive assessment methods available for evaluation of the environmental risks of ionizing radiation. They observed that at many of the mining sites, the measured concentrations of uranium in aquatic plants were not in good agreement with the modeled concentrations in biota as the measured values of uranium were significantly lower than those predicted by the model. Further, they suggested more site-specific assessments of plants and other biota should be carried out since both mobility and bioavailability of uranium to many organisms at the site is likely to be dependent on water chemistry.

Further, using ghost crabs (Ocypode species) as biological indicators, Jonah et al. [40] studied the ecological effects of beach sand mining in Ghana. They reported that ghost crab densities and sizes were negatively affected by both small- and large-scale beach sand mining. Sediment grain sizes and erosion scarp height on beaches were also found to be negatively correlated with burrow density. The groundwater and surface water contamination by mining wastes and its adverse effects on ecology leads to observe different treatment options for mining wastes management before disposal.

\section{Treatment of mining wastes}

Most mines produce tailings as the final waste from mining the ore body, ore processing, and recovering the valuable metals and minerals. Mine tailings are the residue that results from mining, crushing, grinding and chemically treating the ore. The large volume of tailings leading to different environmental footprint in terms of both spatially the storage area and temporally the long-time scales over which tailings must be managed and rehabilitated [28]. Tailings management is a crucial issue in mining operations because of their irreversible impact on the environment. Soil and water quality degradation by current and abandoned mine tailings is a common environmental issue. There are various processes in management of mine tailings such as minimizing tailings production and increasing tailings reuse, adoption of a risk-based approach and considering relevant economic, environmental and social aspects.

Specific tailing properties need to be considered for the proper tailings management. Among the specific properties, for example the presence of sulfide minerals in base and precious metal mine tailings, and the presence of mineral solids in oil sand tailings that are extremely fine and do not readily separate from the process-affected water must be considered by the operator. However, the specific properties of tailings vary with ore type. Process-affected water in tailings pond generally contains metals and acid that must be neutralized prior to disposal. Sulfide mineralization remaining after processing of solid tailings creates a potential environmental problem. Pyrite which produces after deposition of sulfide minerals can oxidize in the presence of infiltrating rainwater or snowmelt to produce sulfuric acid and accelerate the leaching of metals from tailings. Further, the presence of other chemicals in tailings such as surfactants, leaching agents, reagents, solvent extractants, oxidants and other additives in the mining operations also needs to be treated before discharge of tailings [77].

Environmental assessment and regulatory processes that different organizations employ to ensure that the environmental effects of proposed mining projects are identified and the significance of those effects are included in project design prior to regulatory approval must considered tailings management facilities as a key element. Different approaches have been carried out for efficient tailings management. Change in mine tailings properties after application of biochar as a phytostabilization technology was studied by Fellet et al. [32]. They reported that increasing the biochar content in the substrate leads to increase in the $\mathrm{pH}$, the nutrient retention in terms of cation exchange capacity and the water-holding capacity of substrate. Further, they reported that the bioavailability of $\mathrm{Cd}$, $\mathrm{Pb}$ and $\mathrm{Zn}$ of the mine tailings decreased with increasing the biochar content in substrate. Further, they reported that to establish a green cover in a phytostabilization process of mine tailings management, the effect of use of biochar may be considered as an effective option for mine wastes management. Biochar is become a promising heavy metal adsorbent due to its abundance of polar functional groups, such as hydroxyl, carboxylic and amino groups. Biochar has many properties, such as a relatively structured carbon matrix, high degree of microporosity, extensive surface area, and high $\mathrm{pH}$ and cation exchange capacity leading to make it a good adsorbent. 
Fig. 2 Treatment of acid mine drainage (AMD) by using limestone

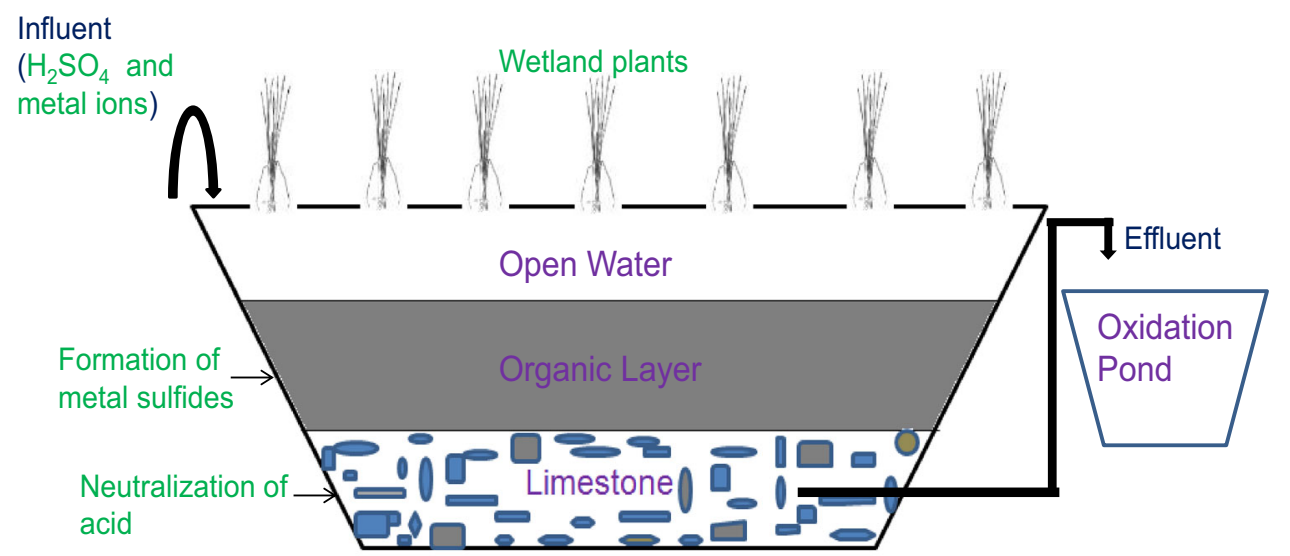

Further, Lee et al. [49] studied the effect of phytostabilization process on metal availability and mobility in mine tailings produced during $\mathrm{Pb} / \mathrm{Zn}$ mining. They reported that risk of mine tailing was successfully controlled by aided phytostabilization and Fe-rich amendments acted as excellent stabilizers of heavy metals in mine tailing. Further, Li et al. [52] studied the microbial diversity and functions in weathered and neutral $\mathrm{Cu}-\mathrm{Pb}-\mathrm{Zn}$ tailings with native soil addition. They reported that in highly weathered and neutral $\mathrm{Cu}-\mathrm{Pb}-\mathrm{Zn}$ tailings, the native soil inoculation approach may be used to fast-track the establishment of native microbial communities and initiate the rehabilitation of biogeochemical processes in the engineered soil for establishing native plant species. A recent study by Cele and Maboeta [18] on properties of biosolids and plants on physicochemical conditions of iron ore tailings showed that biosolids and plants are able to improve conditions related to iron ore mine soil fertility and recolonization of reclaimed sites may be affected by higher metal concentrations.

In order to select one or more AMD control methods for mine operation and closure, different management options should be assessed and compared with respect to their potential environmental impacts. Comparisons are most often based on cost, as well as social impacts and environmental effects. Meschke et al. [57] studied the use of a rotating microfiltration system for the treatment of AMD produced by opencast lignite mining. They reported that to increase the solid content as well as to remove iron hydroxide from $\mathrm{AMD}$, integration of a rotating membrane module may be considered as a suitable option. Neutralization and toxic elements removal from AMD with unmodified and modified limestone was reported by Lakovleva et al. [48]. They reported that for AMD neutralization, the modified limestones can be used as well for the removal of $\mathrm{Fe}(\mathrm{III}), \mathrm{Ni}(\mathrm{II}), \mathrm{Cu}(\mathrm{II})$ and $\mathrm{Zn}$ (II). To treat AMD, different conventional techniques are used such as neutralization and precipitation followed by settling of the precipitates in tailings pond. There are different methods/ techniques used for the neutralization of AMD as well as recovery of metals from AMD such as lime [82] and limestone sand [93], fly ash [36], natural clinker [78] and lignite [63]. AMD management by using lime stone is shown in Fig. 2. For the treatment of AMD and metal sulfides recovery, Xingyu et al. [97] used a novel low $\mathrm{pH}$ sulfidogenic bioreactor using activated sludge as carbon source. They concluded that a sulfidogenic bioreactor process would be a viable method for the treatment of AMD. Sulfidogenic bioreactor processes have three potential advantages over passive biological remediation such as (1) more predictable and controlled performance; (2) selectively recovered of heavy metals, such as copper and zinc from AMD; and (3) significant removal of sulfate from processed affected water. Lee et al. [50] studied $\mathrm{As}(\mathrm{III})$ and $\mathrm{As}(\mathrm{V})$ removal from the aqueous phase via adsorption onto AMD sludge alginate beads and goethite alginate beads. They reported that the manganese oxide present in the AMD sludge enhanced adsorption capacity of As(III) due to oxidation to As(V). Further, they concluded that for the treatment of water contaminated with As, AMD sludge alginate beads may be used as an efficient adsorbent.

\section{Nanoparticles role in mining}

Mining industry has been increasingly involved in nanoscale research, by combining the knowledge of ore properties and extraction methods with the application of nanoengineering. The remediation of AMD waters $(\mathrm{pH}$ 2.3-4.5) contaminated with a suite of metals $(\mathrm{Cu}, \mathrm{Cd}, \mathrm{Ni}$, $\mathrm{Zn}, \mathrm{Hg}, \mathrm{Al}, \mathrm{Mn}$ and $\mathrm{As}$ ) by treating them with granular zero-valent iron was studied by Kim et al. [46]. They found that metal removal and acid neutralization occurred simultaneously and most rapidly within the first $24 \mathrm{~h}$ of reaction and metal removal was most effective in solutions 
that are highly unsaturated with respect to pure-metal hydroxides. Further, use of zero-valent iron and nanosized magnetite with surface coating was studied to enhance the mobility for treatment of mine tailings contain arsenic [46]. They reported that the concentrations of arsenic in leaching solution from mine tailings were significantly reduced after stabilization with nanosized zero-valent iron coated by sodium dodecyl sulfate and nanosized magnetite coated by sodium dodecyl sulfate with a $0.34 \%$ iron/tailing ratio. Role of nanoparticles in controlling arsenic mobilization from sediments near a tailing site was studied by Dong et al. [31]. They reported that the additions of nanoparticles (e.g., $\mathrm{SiO}_{2}, \mathrm{Fe}_{2} \mathrm{O}_{3}$ and $\mathrm{Fe}_{3} \mathrm{O}_{4}$ ) could potentially change the composition of sediment bacterial community and further increase the abundance of $\mathrm{As}(\mathrm{V})$ and $\mathrm{Fe}(\mathrm{III})$ reduction bacteria.

Cyanide de-toxification of mining wastewaters with $\mathrm{TiO}_{2}$ nanoparticles and its recovery by electrocoagulation was studied by Parga et al. [70]. They reported that photodegradation of cyanide is $93 \%$ in 30 min using a $450-\mathrm{W}$ halogen lamp and the recovery of anatase with the electrocoagulation process is $98 \%$. They further concluded that this technique has the potential to serve as a reliable and economical method because sunlight can be used efficiently as the power source. Pollmann et al. [73] studied the application of metal binding by bacteria in bioremediation and nanotechnology in uranium mining waste piles. They reported that in the uranium mining waste piles, higher concentration of toxic metals such as $\mathrm{U}, \mathrm{Cu}, \mathrm{Pb}, \mathrm{Al}$ and $\mathrm{Cd}$ are accumulated in the cell isolates of Bacillus sphaericus. Further, they found that bioaccumulation of metals in the cells serves as a biotreatment for uranium contaminated wastewater, the recovery of metals from electronic wastes as well for the production of metal nanoclusters.

Wu et al. [94] studied the synthesis of $\mathrm{Fe}_{3} \mathrm{O}_{4}$ magnetic nanoparticles from tailings by ultrasonic chemical co-precipitation. They reported synthesis of $\mathrm{Fe}_{3} \mathrm{O}_{4}$ particles with $15 \mathrm{~nm}$ diameter exhibited super-paramagnetic behavior, and $\mathrm{C}_{12} \mathrm{H}_{25} \mathrm{OSO}_{3} \mathrm{Na}$ was added as surface active agent, assisting to obtain $\mathrm{Fe}_{3} \mathrm{O}_{4}$ nanoparticles with homogenous size and shape distribution. Cheng et al. [21] studied the efficient recovery of nanosized iron oxide particles from synthetic AMD water using fuel cell technologies. They reported that the fuel cell technologies can be used for AMD treatment and power generation. They demonstrated that nanosized iron oxide particles can be synthesized from synthetic AMD water using fuel cell technologies and further used as pigments and other applications. Giri et al. [35] studied synthesis and characterization of magnetite nanoparticles using waste iron ore tailings for removal of dyes from aqueous solution. They suggested for possible large-scale application of waste iron ore tailings to synthesize a value added product to treat the wastewaters.
Further, synthesis and characterization of magnetic nanoparticles and their removal capacity of metals from AMD was studied by Kefeni et al. [44]. The study showed that treating AMD with magnetic nanoparticles accelerated formation of ferrites; as a result, magnetic moment of ferrite sludge produced was increased and there may be possibility of synthesis of magnetic nanoparticles from real AMD under cost-effective process by optimizing $\mathrm{pH}$, temperature and string time.

Further, some studies reported the development of nanocomposites using materials from mining industry. The development of cluster assembled materials with size-selected nanoparticles shows great interest for fine-tuning of the properties of the nanoparticles. Vitor et al. [91] studied the adjustment, start-up and long-term performance of a two-stage bioremediation process, treating real AMD, coupled with biosynthesis of $\mathrm{ZnS}$ nanoparticles and $\mathrm{ZnS}$ / $\mathrm{TiO}_{2}$ nanocomposites. They reported that zinc sulfide nanoparticles, both in pure form and as a nanocomposite, $\left(\mathrm{ZnS} / \mathrm{TiO}_{2}\right)$ can be synthesized by using the treated effluent, with excess of biologically generated sulfide. They concluded that the synthesis of zinc sulfide nanoparticles provides the feasibility of coupling an AMD bioremediation system with the synthesis of metal sulfide nanoparticles and nanocomposites. A review by Gamaleia and Shton [34] presents the application of gold mining (gold nanoparticles) for the treatment of photodynamic therapy of tumors (PDT). They concluded that it is feasible to construct gold-containing nanocomposites with higher photodynamic activity and at the same time meeting prescriptive drug requirements. Further, a study of gold grains from tailing piles showed that different factors such as cementation, iron and manganese hydroxides coating, amalgamation, grains growth due to gold particles adsorption and chemical alteration of intermetallic components are directly related to the gold nanoforms modification [15]. Benavente et al. [11] studied the sorption of heavy metals from gold mining wastewater using chitosan. They reported that chitosan is effective to remove metallic ions [ $\mathrm{Cu}(\mathrm{II}), \mathrm{Hg}(\mathrm{II}), \mathrm{Pb}$ (II) and $\mathrm{Zn}$ (II)] above $70 \%$ from gold ore tailing solutions containing cyanide. Further, desorption studies revealed that the type and concentration of the regenerating solution $\left[\mathrm{H}_{2} \mathrm{SO}_{4}, \mathrm{HCl},\left(\mathrm{NH}_{4}\right)_{2} \mathrm{SO}_{4}\right.$, $\mathrm{NaCl}$ and $\mathrm{NaOH}$ ] directly control the regeneration of chitosan saturated with these metallic ions.

Nanoparticles also referred to as "ultrafines" in iron ore tailings have been a source of increase total suspended solids and resulting clays that cannot be easily separated from tailings ponds and impact the discharge waters from tailings ponds. A study by Kotlyar et al. [47] concluded that a high water-holding capacity of oil sands fine tailing was due to the presence of ultrafine $(<0.2 \mu \mathrm{m})$ clay fractions. Hence, the application of nanotechnology in mining 
industry may include different steps such as (1) recovery of metals or metal nanoparticles from mining tailings; (2) the controlled synthesis of metal nanoparticles of well-defined size, shape and composition; (3) nanoparticles incorporation to desired implant surfaces; and (4) synthesis of metalbased nanostructured composites for biomedical and industrial purposes.

\section{Conclusions}

Mine tailings characteristics can vary greatly and are dependent on the ore mineralogy together with the physical and chemical processes used to extract the economic product. Mine tailings entail both an accumulation and a potential subsequent emission source of trace elements $(\mathrm{Cu}, \mathrm{Fe}, \mathrm{Pb}, \mathrm{Zn}$, etc.) with formation of AMD due to the lack of an appropriate extractive technology during the time they were exploited. Potential environmental and socioeconomic considerations need to be balanced to ensure that disposal and storage of tailings occur in a sustainable and responsible manner. Existing strategies for managing tailings are to eliminate or reduce discharge of process-affected water, recovery/removal of metals, to manage dust, and to produce stable landforms within the surrounding environments. Mining tailings pose a high potential risk due to poor water management, failure of the tailings disposal method applied, dam failure and natural disasters.

Considerable focus has been directed toward the development of technologies for the proper management of mine tailings. Nanotechnology plays a greater role in removing heavy metals from AMD and also has value in the secondary recovery of valuable metals from mining waste streams, helping reduce mining's environmental impact. Knowing of the processes occurred in the mine tailings deposits would allow to better assess the level of environmental hazard, suggests the remediation method and/or potential of reuse of the residual materials. Further, enhanced tailings management approaches should necessary to improve the environmental outcomes and reducing overall costs for tailings management systems, as well as minimizing the time required for long-term monitoring and maintenance.

Acknowledgements Funding was provided by National Research Council of Canada.

\section{References}

1. Abdullaev I, Kazbekov J, Manthritilake H (2009) How to establish effective water users groups in Central Asian context. In: Abdullaev I, Mollinga P (eds) Water management in Central Asia: challenges and opportunities. Nova, New York
2. Abdelouas A, Lutze W, Gong W, Nuttall EH (2000) Biological reduction of uranium in groundwater and subsurface soil. Sci Total Environ 250:21-35

3. Akcil A, Koldas KS (2006) Acid mine drainage (AMD): causes, treatment and case studies. J Clean Prod 14:1139-1146

4. Alvarado JAC, Balsiger B, Rollin S, Jakob A, Burger M (2014) Radioactive and chemical contamination of the water resources in the former uranium mining and milling sites of Mailuu Suu (Kyrgyzstan). J Environ Radioact 138:1-10

5. Allert AL, Fairchild JF, DiStefano RJ, Schmitt CJ, Brumbaugh WG, Besser JM (2009) Ecological effects of lead mining on Ozark streams: in-situ toxicity to woodland crayfish (Orconectes hylas). Ecotoxicol Environ Saf 72:1207-1219

6. Alvarez-Ayuso E, Abad-Valle P, Murcigeo A, Villar-Alonso P (2016) Arsenic distribution in soils and rye plants of a cropland located in an abandoned mining area. Sci Total Environ 542:238-246

7. Amezaga JM, Rotting TS, Younger PL (2011) Arich vein? Mining and the pursuit of sustainability. Environ Sci Technol 45:21-26

8. Atkins ML, Santos IR, Perkins A, Maher DT (2016) Dissolved radon and uranium in groundwater in a potential coal seam gas development region (Richmond River Catchment, Australia). J Environ Radioact 154:83-92

9. Bacquart T, Frisbie S, Mitchell E, Grigg L (2015) Multiple inorganic toxic substances contaminating the groundwater of Myingyan Township, Myanmar: arsenic, manganese, fluoride, iron, and uranium. Sci Total Environ 517:232-245

10. Bertrand G, Hirata R, Pauwels H, Cary L (2016) Groundwater contamination in coastal urban areas: anthropogenic pressure and natural attenuation processes. Example of Recife (PE State, NE Brazil). J Contam Hydrol 192:165-180

11. Benavente M, Moreno L, Martinez J (2011) Sorption of heavy metals from gold mining wastewater using chitosan. J Taiwan Inst Chem Eng 42:976-988

12. Besser JM, Brumbaugh WG, Allert AL, Poulton BC, Schmitt CJ, Ingersoll CG (2009) Ecological impacts of lead mining on Ozark streams: toxicity of sediment and pore water. Ecotoxicol Environ Saf 72:516-526

13. Bhattacharya P, Sracek O, Eldvall B, Asklund R, Barmen G et al (2012) Hydrogeochemical study on the contamination of water resources in a part of Tarkwa mining area, Western Ghana. J Afr Earth Sci 66-67:72-84

14. Bhattacharya P, Frisbie SH, Smith E, Naidu R, Jacks G, Sarkar B (2002) Arsenic in the environment: a global perspective. In: Sarkar B (ed) Handbook of heavy metals in the environment. Marcell Dekker, New York, pp 147-215

15. Borisovna NO, Naumov VA, Osovetskiy BM, Lunev BS, Kovin ON (2013) Nanoforms of secondary gold in the tailings wastes: placers of is river, Russia. Middle-East J Sci Res 18:316-320

16. Boelens R, Getches D, Guevara Gil JA (eds) (2010) Out of the mainstream: water rights, politics and identity. Earthscan/ Routledge, London, p 360

17. Bunton TE, Frazier JM (1994) Extrahepatic tissue copper concentrations in white perch with hepatic copper storage. J Fish Biol 45(4):627-640

18. Cele EN, Maboeta M (2016) A greenhouse trial to investigate the ameliorative properties of biosolids and plants on physicochemical conditions of iron ore tailings: implications for an iron ore mine site remediation. J Environ Manag 165:167-174

19. Chakraborti D, Rahman MM, Ahmad S, Dutta RN (2016) Arsenic groundwater contamination and its health effects in Patna district (capital of Bihar) in the middle Ganga plain, India. Chemosphere 152:520-529

20. Charalambous C, Aletrari M, Piera P, Kanari PN (2013) Uranium levels in Cypriot groundwater samples determined by ICPMS and $\alpha$-spectroscopy. J Environ Radioact 116:187-192 
21. Cheng S, Jang JH, Dempsey BA, Logan BE (2011) Efficient recovery of nano-sized iron oxide particles from synthetic acidmine drainage (AMD) water using fuel cell technologies. Water Res 45:303-307

22. Clements WH (2000) Integrating effects of contaminants across levels of biological organization: an overview. J Aquat Ecosyst Stress Recovery 7:113-116

23. Clements WH, Kiffney PM (1994) Assessing contaminant impacts at higher levels of biological organization. Environ Toxicol Chem 13:397-404

24. Concas A, Ardau C, Cristini A, Zuddas P, Cao G (2006) Mobility of heavy metals from tailings to stream waters in a mining activity contaminated site. Chemosphere 63:244-253

25. Coller-Myburgh CV, Rensburg LV, Maboeta M (2014) Utilizing earthworm and microbial assays to assess the ecotoxicity of chromium mine wastes. Appl Soil Ecol 83:258-265

26. Das N, Deka JP, Shim J, Patel AK, Kumar A (2016) Effect of river proximity on the arsenic and fluoride distribution in the aquifers of the Brahmaputra floodplains. Groundwater Sustainable Development, Assam. doi:10.1016/j.gsd.2016.07.001

27. DeNicola DM, Stapleton MG (2002) Impact of acid mine drainage on benthic communities in streams: the relative roles of substratum vs. aqueous effects. Environ Pollut 119:303-315

28. Department of Industry, Tourism and Resources (DITR) (2007) Tailings management, Leading Practice Sustainable Development Program (LPSDP) for the mining industry. Department of Industry, Tourism and Resources, Canberra

29. Dhakate R, Singh VS, Hodlur GK (2008) Impact assessment of chromite mining on groundwater through simulation modeling study in Sukinda chromite mining area, Orissa, India. J Hazard Mater 160:535-547

30. Dhillon KS, Dhillon SK (2016) Selenium in groundwater and its contribution towards daily dietary $\mathrm{Se}$ intake under different hydrogeological zones of Punjab, India. J Hydrol 533:615-626

31. Dong G, Huang Y, Yu Q, Wang Y, Wang H, He N, Li Q (2014) Role of nanoparticles in controlling arsenic mobilization from sediments near a realgar tailing. Environ Sci Technol 48:7469-7476

32. Fellet G, Marchiol L, Vedove GD, Peressotti A (2011) Application of biochar on mine tailings: effects and perspectives for land reclamation. Chemosphere 83:1262-1267

33. Forcada EG, Alegre MV (2015) Arsenic, barium, strontium and uranium geochemistry and their utility as tracers to characterize groundwaters from the Espadán-Calderona Triassic Domain, Spain. Sci Total Environ 512-513:599-612

34. Gamaleia NF, Shton IO (2015) Gold mining for PDT: great expectations from tiny nanoparticles. Photodiagn Photodyn Ther $12: 221-231$

35. Giri SK, Das NN, Pradhan GC (2011) Synthesis and characterization of magnetite nanoparticles using waste iron ore tailings for adsorptive removal of dyes from aqueous solution. Colloids Surf A Physicochem Eng Asp 389:43-49

36. Gitari WM, Petrik LF, Etchebers O, Key DL, Okujeni C (2008) Utilization of fly ash for treatment of coal mines wastewater: solubility controls on major inorganic contaminants. Fuel $87: 2450-2462$

37. Gude JCJ, Rietveld LC, Halem D (2016) Fate of low arsenic concentrations during full-scale aeration and rapid filtration. Water Res 88:566-574

38. Gong XY, Brueck H, Giese KM, Zhang L, Sattelmacher B, Lin S (2008) Slope aspect has effects on productivity and species composition of hilly grassland in the Xilin river basin, Inner Mongolia, China. J Arid Environ 72:483-493

39. Guo H, Adhikary D, Craig MS (2006) Integrated approach to mine water assessment. In: Proceedings of water in mining 2006, Brisbane
40. Jonah FE, Agbo NW, Agbeti W, Adjei-Boateng D, Shimba MJ (2015) The ecological effects of beach sand mining in Ghana using ghost crabs (Ocypode species) as biological indicators. Ocean Coast Manag 112:18-24

41. Jung HB, Zheng Y, Rahman MW, Rahman MM, Ahmed KM (2015) Redox zonation and oscillation in the hyporheic zone of the Ganges-Brahmaputra-Meghna delta: implications for the fate of groundwater arsenic during discharge. Appl Geochem 63:647-660

42. Juanjuan S, Zhigang Y, Bochao X, Wenhua D, Dong X, Xueyan $\mathrm{J}$ (2014) Concentrations and fluxes of dissolved uranium in the Yellow River estuary: seasonal variation and anthropogenic (Water-Sediment Regulation Scheme) impact. J Environ Radioact 128:38-46

43. Kayzar TM, Villa AC, Lobaugh ML, Gaffney AM, Williams RW (2014) Investigating uranium distribution in surface sediments and waters: a case study of contamination from the Juniper Uranium Mine, Stanislaus National Forest, CA. J Environ Radioact 136:85-97

44. Kefeni KK, Msagati TM, Mamba BB (2015) Synthesis and characterization of magnetic nanoparticles and study their removal capacity of metals from acid mine drainage. Chem Eng J 276:222-231

45. Kemp D, Bond CJ, Franks DM, Cote C (2010) Mining, water and human rights: making the connection. J Clean Prod 18:1553-1562

46. Kim KR, Lee BT, Kim KW (2012) Arsenic stabilization in mine tailings using nano-sized magnetite and zero valent iron with the enhancement of mobility by surface coating. J Geochem Explor 113:124-129

47. Kotlyar LS, Sparks BD, Woods J, Capes CE, Schutte R (1995) Biwetted ultrafine solids and structure formation in oil sands fine tailings. Fuel 74:1146-1149

48. Lakovleva E, Makila E, Salonen J, Sitarz M, Wang S, Sillanpaa M (2015) Acid mine drainage (AMD) treatment: neutralization and toxic elements removal with unmodified and modified limestone. Ecol Eng 81:30-40

49. Lee SH, Ji W, Lee W, Koo N, Koh IH, Kim MS, Park J (2014) Influence of amendments and aided phytostabilization on metal availability and mobility in $\mathrm{Pb} / \mathrm{Zn}$ mine tailings. J Environ Manag 139:15-21

50. Lee H, Kim D, Kim J, Ji MK, Han YS, Park YT, Yun HS, Choi J (2015) As(III) and As(V) removal from the aqueous phase via adsorption onto acid mine drainage sludge (AMDS) alginate beads and goethite alginate beads. J Hazard Mater 292:146-154

51. Leybourne MI, Cameron EM (2008) Source, transport, and fate of rhenium, selenium, molybdenum, arsenic, and copper in groundwater associated with porphyry- $\mathrm{Cu}$ deposits, Atacama Desert, Chile. Chemical Geology 247:208-228

52. Li X, You F, Bond PL, Huang L (2015) Establishing microbial diversity and functions in weathered and neutral $\mathrm{Cu}-\mathrm{Pb}-\mathrm{Zn}$ tailings with native soil addition. Geoderma 247-248:108-116

53. Liesch T, Hinrichsen S, Goldscheider N (2015) Uranium in groundwater-fertilizers versus geogenic sources. Sci Total Environ 536:981-995

54. Lottermoser B (2012) Mine wastes: characterization, treatment and environmental impacts. Springer, New York, p 400

55. Luptakova A, Ubaldini S, Macingova E, Fornari P, Giuliano V (2012) Application of physical-chemical and biological-chemical methods for heavy metals removal from acid mine drainage. Process Biochem 47(11):1633-1639

56. Lu S, Wang Y, Teng Y, Yu X (2015) Heavy metal pollution and ecological risk assessment of the paddy soils near a zinc-lead mining area in Hunan. Environ Monit Assess 187:627

57. Meschke K, Herdegen V, Aubel T, Janneck E, Repke J (2015) Treatment of opencast lignite mining induced acid mine 
drainage (AMD) using a rotating microfiltration system. J Environ Chem Eng 3:2848-2856

58. Miranda M, Sauer A (2010) Mine the gap: connecting water risks and disclosure in the mining sector. World Resources Institute, Washington

59. Miao Z, Carroll KC, Brusseau ML (2013) Characterization and quantification of groundwater sulfate sources at a mining site in an arid climate: The Monument Valley site in Arizona, USA. J Hydrol 504:207-215

60. Milja TE, Prathish KP, Rao TP (2011) Synthesis of surface imprinted nanospheres for selective removal of uranium from simulants of Sambhar salt lake and ground water. J Hazard Mater 188:384-390

61. Mills TJ, Mast MA, Thomas J, Keith G (2016) Controls on selenium distribution and mobilization in an irrigated shallow groundwater system underlain by Mancos Shale, Uncompahgre River Basin, Colorado, USA. Sci Total Environ 566-567:1621-1631

62. Moriarty MM, Lai VWM, Kock I, Cui L, Combs C, Krupp EM (2014) Speciation and toxicity of arsenic in mining-affected lake sediments in the Quinsam watershed, British Columbia. Sci Total Environ 466-467:90-99

63. Mohan D, Chander S (2006) Removal and recovery of metal ions from acid mine drainage using lignite-a low cost sorbent. J Hazard Mater 137:1545-1553

64. Montufar JCB, Cortes MR, Cortes IAR, Valdez MSE (2012) Uranium-series isotopes transport in surface, vadose and ground waters at San Marcos uranium bearing basin, Chihuahua, Mexico. Appl Geochem 27:1111-1122

65. Mudd G, Boger DV (2013) The ever growing case for paste and thickened tailings e towards more sustainable mine waste management. Aust Inst Min Metall Bull 2:56-59

66. Munoz MO, Arostegui JLG, Bhattacharya P, Sracek O (2016) Geochemistry of naturally occurring arsenic in groundwater and surface-water in the southern part of the Poopó Lake basin, Bolivian Altiplano. Groundw Sustain Dev 2-3:104-116

67. Nriagu J, Nam DH, Ayanwola TA, Dinh H (2012) High levels of uranium in groundwater of Ulaanbaatar, Mongolia. Sci Total Environ 414:722-726

68. Okelsrud A, Lydersen E, Fjeld E (2016) Biomagnification of mercury and selenium in two lakes in southern Norway. Sci Total Environ 566-567:596-607

69. Oughton DH, Stromman G, Salbu B (2013) Ecological risk assessment of Central Asian mining sites: application of the ERICA assessment tool. J Environ Radioact 123:90-98

70. Parga JR, Vazquez V, Casillas HM, Valenzuela JL (2009) Cyanide detoxification of mining wastewaters with $\mathrm{TiO}_{2}$ nanoparticles and its recovery by electrocoagulation. Chem Eng Technol 32:1901-1908

71. Pascaud G, Leveque T, Soubrand M, Boussen S, Joussein E, Dumat C (2014) Environmental and health risk assessment of $\mathrm{Pb}, \mathrm{Zn}, \mathrm{As}$ and $\mathrm{Sb}$ in soccer field soils and sediments from mine tailings: solid speciation and bioaccessibility. Environ Sci Pollut Res 21:4254-4264

72. Pascaud G, Boussen S, Soubrand M, Joussein E, Fondaneche P, Abdeljaouad S, Bril H (2015) Particulate transport and risk assessment of $\mathrm{Cd}, \mathrm{Pb}$ and $\mathrm{Zn}$ in a Wadi contaminated by runoff from mining wastes in a carbonated semi-arid context. J Geochem Explor 152:27-36

73. Pollmann K, Raff J, Merroun M, Fahmy K, Selenska-Pobell S (2006) Metal binding by bacteria from uranium mining waste piles and its technological applications. Biotechnol Adv 24:58-68

74. Rahman MA, Rahman MM, Reichman SM, Lim RP, Niadu R (2014) Heavy metals in Australian grown and imported rice and vegetables on sale in Australia: health hazard. Ecotoxicol Environ Saf 100:53-60

75. Rahman MM, Dong Z, Naidu R (2015) Concentrations of arsenic and other elements in groundwater of Bangladesh and West Bengal, India: potential cancer risk. Chemosphere 139:54-64

76. Reyes FAP, Crosta GB, Frattini P, Basirico S, Pargola RD (2015) Hydrogeochemical overview and natural arsenic occurrence in groundwater from alpine springs (upper Valtellina, Northern Italy). J Hydrol 529:1530-1549

77. Ritcey GM (2005) Tailings management in gold plants. Hydrometallurgy 78:3-20

78. Rios CA, Williams CD, Roberts CL (2008) Removal of heavy metals from acid mine drainage (AMD) using coal fly ash, natural clinker and synthetic zeolites. J Hazard Mater 156:23-35

79. Rubio RF (2012) Mining: the challenge knocks on our door. Mine Water Environ 31:69-73

80. Salvarredy-Aranguren MM, Probst A, Roulet M, Isaure MP (2008) Contamination of surface waters by mining wastes in the Milluni Valley (Cordillera Real, Bolivia): mineralogical and hydrological influences. Appl Geochem 23:1299-1324

81. Shin W, Oh J, Choung S, Cho BW, Lee KS (2016) Distribution and potential health risk of groundwater uranium in Korea. Chemosphere 163:108-115

82. Silveira AN, Silve R, Rubio J (2009) Treatment of acid mine drainage (AMD) in South Brazil: comparative active processes and water reuse. Int J Miner Process 93:103-109

83. Singh B, Kataria N, Garg VK, Yadav P (2014) Uranium quantification in groundwater and health risk from its ingestion in Haryana, India. Toxicol Environ Chem 96:1571-1580

84. Silva ML, Bonotto DM (2015) Uranium isotopes in groundwater occurring at Amazonas State, Brazil. Appl Radiat Isot 97:24-33

85. Smedley PL, Kinniburgh DG (2002) A review of the source, behaviour and distribution of arsenic in natural waters. Appl Geochem 17:517-568

86. Sracek O, Kribek B, Mihaljevic M, Majer V, Veselovsky F (2012) Mining-related contamination of surface water and sediments of the Kafue River drainage system in the Copperbelt district, Zambia: an example of a high neutralization capacity system. J Geochem Explor 112:174-188

87. Sundaray SK, Nyak BB, Lin S, Bhatta D (2011) Geochemical speciation and risk assessment of heavy metals in the river estuarine sediments-a case study: Mahanadi basin, India. J Hazard Mater 186:1837-1846

88. Toran L (1987) Sulfate contamination in groundwater from a carbonate-hosted mine. J Contam Hydrol 2:1-29

89. Tonder GV, Usher BH, Dennis I, Vermeulen PD (2007) Predicting rebound in a deep colliery in South Africa. Mine Water Environ 26:79-87

90. Verma S, Mukherjee A, Choudhury R, Mahanta C (2015) Brahmaputra river basin groundwater: solute distribution, chemical evolution and arsenic occurrences in different geomorphic settings. J Hydrol Reg Stud 4:131-153

91. Vitor G, Palma TC, Veira B, Lourenco JP, Barros RJ, Costa MC (2015) Start-up, adjustment and long-term performance of a two-stage bioremediation process, treating real acid mine drainage, coupled with biosynthesis of $\mathrm{ZnS}$ nanoparticles and $\mathrm{ZnS}$ / $\mathrm{TiO}_{2}$ nanocomposites. Miner Eng 75:85-93

92. Vicente-Martorell JJ, Galindo-Riaño MD, García-Vargas M, Granado-Castro MD (2009) Bioavailability of heavy metals monitoring water, sediments and fish species from a polluted estuary. J Hazard Mater 162:823-836

93. Watten BJ, Sibrell PL, Schwartz MF (2005) Acid neutralization within limestone sand reactors receiving coal mine drainage. Environ Pollut 137:295-304 
94. Wu S, Sun A, Zhai F, Wang J, Xu W, Zhang Q, Vollinsky AA (2011) $\mathrm{Fe}_{3} \mathrm{O}_{4}$ magnetic nanoparticles synthesis from tailings by ultrasonic chemical co-precipitation. Mater Lett 65:1882-1884

95. Wu YH, Zhang WQ, Zhao KQ (2009) Comprehensive prevention technology research of mine water disaster. China University of Mining and Technology Press, Xuzhou, pp 200-202

96. Wurl J, Mendez-Rodriguez L, Acosta-Vargas B (2014) Arsenic content in groundwater from the southern part of the San Antonio-El Triunfo mining district, Baja California Sur, Mexico. J Hydrol 518:447-459

97. Xingyu L, Gang Z, Xiaoqiang W, Laichang Z, Jiankang W, Renman R, Dianzuo W (2013) A novel low pH sulfidogenic bioreactor using activated sludge as carbon source to treat acid mine drainage (AMD) and recovery metal sulfides: pilot scale study. Miner Eng 48:51-55

98. Zabey E, Boffi AL (2009) Why water is everyone's business. http://www.wbcsd.org/Plugins/DocSearch/details.asp?DocTypeId $=251 \&$ ObjectId=MzY5OTc

99. Zhang J, Peng S (2005) Water inrush and environmental impact of shallow seam mining. Environ Geol 48:1068-1076

100. Zhuang P, McBride MB, Xia H, Li N, Zhian Li (2009) Health risk from heavy metals via consumption of food crops in the vicinity of Dabaoshan mine, South China. Sci Total Environ 407:1551-1561 